Global Conferences Series:

Social Sciences, Education and Humanities (GCSSSEH), Volume 3, 2019

The $1^{\text {st }}$ International Conference on Education, Social Sciences and Humanities

DOI: https://doi.org/10.326/hum0194

\title{
Teaching Materials and Delivery Strategies of Arts Materials Studies in The Disruption Era
}

\author{
Purwatiningsih $^{1}$, Tjitjik Sriwardhani $^{2}$ \\ 1,2 Universitas Negeri Malang \\ purwatiningsih022@gmail.com
}

\begin{abstract}
Arts teacher understand how to find and develop teaching materials that must be adjusted to the curriculum content standards. Arts teaching materials included in books, hand outs, modules, worksheets, and other learning media.There are many teachers who haven't been able to anticipate, while students can even more quickly anticipate technological developments, but sometimes it show the wrong concept. This study aims to describe the arts teaching materials used by art teachers in schools and find appropriate delivery strategies to anticipate rapid development of information technology in the desruption era. In this survey research, data searching was done by distributing questionnaires, interviews and observations on 18 teachers from 18 high schools in Malang, and the results were processed using descriptive analysis. The results indicate that many art teaching materials are packaged in the form of textbooks, modules, worksheets, models, presentations, interactive media and those developed by the teachers. Also many sources obtained from the internet. Sientific, inductive, deductive, discovery, inquiry, heuristic, PBL, PjBL, is an approach that gives students freedom to develop the material taught. In conclusion, any delivery strategy implemented by the teacher requires wise management in anticipating technological developments in the disruption era, and must be monitored for misconceptions.
\end{abstract}

Keywords: Teaching Materials, Arts, Delivery Strategies

\section{Introduction}

High school education is education for adolescents who currently enter as a generation that is very vulnerable to negative influences in everything, especially in the current era of disruption. No exception in art learning at school. Learning art contains teaching materials developed based on curriculum content standards currently in use, namely the revised 2013 curriculum in 1916. Art teachers have been given examples of teaching materials published by Puskur. The book is called a baboon book because it consists of all sub-fields of art, namely art, music, dance and theater. Thus the teaching materials of art in the book are very minimal. The rest of the art teachers can develop their own art teaching materials needed in the learning process in accordance with the prota (annual program) and promes (semester program). 
At the beginning of the 2013 curriculum implementation, because it was still new, the baboon book was only used by the teacher and student. What happens in the field, students and teachers are only pegged to the teaching materials and cannot cover the entire contents of basic competencies. This is the same as the results of observations of researchers in Malang and several other areas in Indonesia, it turns out the discussion is all together and there is no variation. If this happens for the future, where do we want our next generation to be? They don't know much. Students become stuck not developing and there are no new innovations. This was then realized by the art teachers, as content standards begin to be understood, the teacher begins to develop other teaching materials that can be derived from available competencies. Teaching materials that are made according to the ability of the teacher (Iriaji, 2016). The era of technological advancements in carrying gadgets into schools, which were used to hide in secret, was banned and now it's clear and permissible. They are in the form of cellphones, smartphones, tablets, notebooks, MP3 players, Ipods, walkmans. Stylish, contemporary, small, practical and easy to carry everywhere. This is a teacher's challenge

This study aims to describe 1). Map of teaching materials developed by visual arts teachers as a form of fulfillment of content standards in Permendikbud No. 24 of 2016; 2) teaching materials developed are realized through any media; 3 ) the way the teacher develops teaching materials, and 4) strategies for delivering art teaching materials to students. This research was carried out because it was directed at the phenomenon of the activities of students who actually obtained information from sources that could not be accounted for, even sometimes information through the media was misleading but it was even more interesting than the teaching materials provided by the teacher at school.

The existence of teaching materials is closely related to learning facilities that must be properly prepared by the teacher. Therefore "the condition of the learning must be taken into consideration in the development of teaching materials" (Soehardjo, 2011: 165) Therefore the main focus of this research is the form of teaching materials, development processes and delivery strategies to students, which are explored through questionnaires, observations and interviews. Delivery strategies of teaching materials is teacher's tips so that teaching materials that have been designed can be conveyed and their success can be measured. The research findings indicate that teaching materials have all been derived from curriculum content standards with basic competency in knowledge and basic skills competency. Its form becomes a medium of print, non-print, audio, video, and interactive teaching materials. The teaching material is made by the teacher himself or obtained from various sources. The delivery strategy uses 3 types of approaches, namely approaches to teaching material knowledge, appreciation and skills. These findings are very necessary for art teachers. Furthermore, art teachers can really give full attention to the development of students when and after the delivery of teaching materials, because the development of technology is unlimited and unstoppable. In conclusion, art teachers must be innovative, and also need to keep up with the flow of technological development. This research can be used as a motivation to carry out "Sustainable Innovation in The Digital Era". Hoped that other studies will be able to better capture the phenomenon in more detail about this. Will the teacher be static in the strategy of delivering teaching materials in traditional ways and cannot compensate for the nature of students who seem to want to run as the $\mathrm{X}$ generation in this disruption era?

\section{Method}

In the Method section, you explain clearly how you conducted your study in order to: (1) enable readers to evaluate the work performed and (2) permit others to replicate your study. You must describe exactly what you did: what and how experiments were run, what, how much, how often, where, when, and why equipment and materials were used. The main consideration is to ensure that enough detail is provided to verify your findings and to enable the replication of the study. You should maintain a balance between brevity (you cannot describe every technical issue) and completeness (you need to give adequate detail so that readers know what happened). 
This research was conducted by selecting 18 senior high schools in Malang with each of the 1 respondent being used as footage representing art teachers from the school. This is done because there are schools that have more than one teacher. The instruments used were questionnaires, interviews, observation and discussion. From the questionnaire that was distributed, it was obtained an overview that was still general in nature and needed to be reaffirmed so that observations and interviews were conducted to the respondents. The research was carried out for 8 months, March to October in 2017. The researchers also involved several students to provide research experience. The data obtained were analyzed descriptively qualitatively, although there were quantitative data. The validity of this research is done by triangulating the data and triangulating the source, so that the data reported by the researcher is in accordance with the actual data in the field (Soetopo, 2002) "Validity in qualitative research shows the extent to which the level of interpretation and conceptual concepts obtained has meaning that is appropriate between researchers and participants" (Ma'rifah, 2014) All of that is carried out based on the assumption that the researcher has interpreted what was obtained in accordance with the actual conditions. This research was conducted with limited time so that the validity of the data is only done by data triangulation and source triangulation. We have a new method has been developed using the Whatsapp facility to discuss findings. Whatsapp is used as a tool for source triangulation. From the discussion in this application, there were many things that were obtained

\section{Results and Discussion}

The first results of the study indicate that teaching materials developed by visual arts teachers depart from the basic competencies of knowledge and basic skills competencies. From knowledge competencies, teaching materials that emerge are the Concept of Culture, Basic Culture, Basic Art, Concept of Art, Concept of Art, Concept of Beauty, Basic Oil Painting, Art Appreciation, Art Criticism, Basic Drawing Technique, Archipelago Temple Appreciation, Definition Cultural Arts, Art Elements, Appreciation of Cultural Elements, History of Visual Arts, History of Eastern Art, Flow of Art, Painting Technique, Art Exhibition, Art Criticism, Art Criticism, Traditional Carving Motif, Fine Art, Performing / Exhibition Art, Engineering make sculptures. From the basic competencies the following skills arise from teaching materials. Nirmana 2 Dimensions, Artistic Organization, Nirmana 3 Dimensions, Composition of Nirmana, Oman nirmana 2 Dimensions, Nirmana line, Nirmana point, Visual Art 2 Dimensions, Image of character, Visual Art 3 Dimensions, Picture of shape, Picture of motif, Painting watercolor, Oil painting, fabric painting, glass painting, acrylic painting, Renew product design, Advertising products, Photography, Posters, Perspectives, Image shapes, 2dimensional model drawings, 3-dimensional model drawings, Perspective drawings, Pictures. Illustrations, Comic drawings, figurative pictures, oil paints, technical drawings, decorative drawings, linear drawings, printed crafts, printed arts, mask printing, recycled masks, Malang masks, batik crafts, batik printing, pigment decoration, Painting pointillism, Dry leaf craft, Waste craft, 3D dimensional painting, pottery painting, Malang Woven mask, Decorative, mockup, wooden craft, textile, Interior design, Projection, Screen printing, Exhibition, Performing arts, ceramics, puppet cartons, Sculptures, Tapestry, Knitting / embroidery, 2D works and 3D works.. These variations indicate the effort to meet the content standards in Permendikbud No. 24 of 2016;

The second result of the learning material that is used or developed by the teacher to support the learning that has been designed by the teacher is realized in the learning media as the channel. The media are in the form of textbooks, enrichment books, modules, worksheets, brochures, leaflets, walkchart, photos / drawings, models, mockups, practicum instructions, tapes, radio / television, compact disks, flashdisk, cellphone, films, slides, powerpoint, flash, Performances / exhibitions. Interactive CD, Educational Games. handphone, smartphone, tablet, notebook, MP3 Player, Ipod, walkman.

The third results of developing teaching materials process conducted by teachers varied greatly. There are most teachers who still feel difficulties in developing self-made teaching materials, so 
finding existing teaching materials and opening up opportunities for students to find teaching materials on the internet.

The fourth result, the delivery of fine arts teaching materials uses a variety of approaches that always end with reflection to reduce misconceptions for both knowledge competencies and skills competencies. There are 3 types of approaches carried out by the teacher in the delivery of knowledge teaching materials namely a) Expository, where message management is carried out by the teacher, so that students tend to be passive, so it must be combined with other strategies that activate students; b) Heuristics, where message processing is carried out by students, so that they become active; c) Inductive and deductive, which can be programmed so that students become more active. The introduction process starts from finding things that are specific to the general or vice versa from the general to the specific. This approach is encapsulated in various art learning models.

For skills teaching materials are used 3 types of approaches, namely a) Formal approach which is a learning or working activity. The appearance of students is based on patterns given by art teachers, which can be classified into patterns in the form of examples, patterns in the form of patra or notation, patterns in the form of models, and patterns in the form of verbal descriptions. The pattern in the form of an example is an activity of making or duplicating existing forms. The pattern in the form of patra or notation, is the activity of making or doing an imitation of an existing form. Patterns in the form of verbal descriptions, are activities to realize a theme or title that has been given complete signs or binding provisions, so that students do not get the opportunity to make their own interpretations; b). Informal approach (free expression), is a work activity carried out by students based on their own ideas. This activity can be categorized as creating activities; and c). Functional approach, is a work activity carried out by students based on teacher direction. This activity can be categorized as creating or changing activities, but the results are not purely student discovery. It is possible in the form of a new form that is changed from an old or traditional form. Furthermore, the application in the class depends on the characteristics of students.

From the results of the study above, the scope of teaching materials, the media used, and the development process, there is no urgent problem. But keep in mind that teaching materials that have been developed by the teacher are still possible to be developed again, and this is very important for teachers to know. While the media as a channel also needs to keep up with the flow of development. Instead, the delivery strategies of teaching materials that need to be observed by the teacher. The approach directed in 2013 curriculum learning is indeed more student oriented, which is more directed to meeting the needs and interests of students. Thus the teacher must know more about the needs and interests of the student. According to Luzanov in DePorter (2002: 3), "the learning process is a complex phenomenon. Everything matters. Every word, thought, action, association and to what extent the teacher changes the environment, presentation and design of learning, so far the learning process takes place ". The process of learning art also needs to be designed for this.

The development of basic competencies that exist in the current art curriculum is suspected of the emergence of knowledge teaching materials that replace appreciation teaching materials. Appreciation is more emphasized in the attitude of respect for artwork with all its elements. The approach to the delivery of teaching materials for the art connoisseurs is done by means of analysis and familiarity / empathic (Purwatiningsih, 2012). The analytical approach consists of an inductive, interactive and deductive approach. Inductive approach is an individual activity in analyzing artistic works based on reasoning that moves from specific things to the general. The interactive approach is an inductive approach carried out by the group by means of discussion. Deductive approach is an individual activity in analyzing artistic works based on reasoning that moves from the principle or general things to specific things. In the analysis approach mentioned above, the teacher equips students with theoretical knowledge that can be provided while carrying out guidance or direction. $b$ ) Familiarity approach. Based on the theory of empathy in art, observers / viewers in this case are students, taking part in the scenes depicted by artists. As if he was the real culprit, so that his feelings became confined to the atmosphere observed. Students as observers who can act as such are students who are sensitive to art, and this sensitivity is gained from the experience of familiarizing art. For 
example, in seeing an exhibition, intimacy will grow and sensitivity will gradually develop. Teachers can provide opportunities for students to see performances / exhibitions without providing knowledge beforehand but aim at what its felt when students enjoy the work seen. However, education, attitude and character can also be through the delivery of teaching materials for enjoyment.

Iriaji 2016 shows that the learning process of appreciation generates and shapes students' knowledge. Art teachers should not necessarily abandon the concept of appreciation as a way of delivering teaching materials, so the ultimate goal of learning is not just to know their knowledge and just be able to work in art. Media obtained on the internet is more practical, procedural and immediately shows results. But sometimes there is a wrong concept. This wrong concept is what teachers must watch out for. The phenomenon above is very alarming if the art teacher is only based on knowledge and skills while the flavoring is not mentioned at all. Is the curriculum wrong or is the teacher understanding in interpreting a less observant curriculum. Hopefully there are other studies that can better capture the phenomenon in more detail about this. Besides that, will the teacher be static in the strategy of delivering teaching materials in traditional ways without effort to keep up with the flow of technological development? Should the teacher be able to balance the nature, conditions and interests of students who can quickly doing work? "Interest in a simple way can be understood as a tendency and high enthusiasm or desire for something" (Karwati, 2014: 148). As dePorter suggested in his book entitled Quantum teaching (2002: 154), "Provide students with a condition, so you will improve their ability to understand, participate, focus, and absorb information".

With the entry of new media in schools, how art teachers respond to and take advantage of the conditions of today's students, making teachers must immediately make new innovations in the delivery strategies of teaching materials. Available teaching materials that are varied, innovative, and interesting make learning activities more attractive, more students have the opportunity to learn independently, and have the ease of learning (Prastowo, 2012: 27). Based on the existing learning model model with innovative modifications can be an alternative to maintain so that learning continues to take place joyfully learning.

\section{Conclusions}

In conclusion, various teaching materials have been developed by art teachers. This shows that the teacher has made various efforts to meet the content standards in Permendikbud No. 24 of 2016. However, the present material is less visible so that the teacher still needs to deepen and expand the field of study which is currently starting to emerge and can be used as teaching material.

Teaching materials developed by teachers in the form of print media, media events / activities, audio / audio visual and interactive media. But most teachers still have difficulties in developing selfmade teaching materials, thus opening opportunities for students to find teaching materials on the internet. Many applications can be used to create media by utilizing today's technology, but even then it needs to be mastered by the teacher. Thus there needs an effort to learn to package teaching materials through IT-based media so that they can offset the rapid development of technology.

Delivering of art teaching materials uses a variety of approaches that always end with reflection to reduce misconceptions brought from internet information. The teacher can use existing strategies, approaches or learning models or new models that are appropriate to the conditions of the needs and interests of the students. Even more important is that developing teaching materials does not leave behind the development of aesthetic sense through art appreciation learning even through the knowledge and skills competencies listed in the curriculum. 


\section{Acknowledgments}

We would like to express the special thanks to the high schools of Arts Teacher. They give some information that is very useful in this research. Also to the research team as well as students who diligently help search and examine the data obtained. Thank you also to the research fund who in this case is the ranks of faculty officials who have given permission to carry out this research. Then apologize to all parties who feel disturbed and take the time to just provide information.

\section{References}

Degeng, I Nyoman Sudana. (2001). Pedoman Penulisan Buku Ajar. Malang: LP3 UM.

DePorter, Bobby.dkk. (2002).Quantum Teaching. Bandung: penerbit Kaifa.

Iriaji. (2016). Pengembangan Model dan Materi Pembelajaran Apresiasi Seni dengan Pendekatan Asosiatif Berbasis Keragaman Seni Nusantara untuk Siswa SMA. Laporan Penelitian. Malang : LP2M $\mathrm{UM}$

Iriaji. (2011). Konsep dan Strategi Pembelajaran Seni Budaya. Malang : Pustaka Kaiswaran.

Jazuli.M. (2008). Paradigma Kontekstual Pendidikan Seni. Semarang : Unesa University Press

Marifah, Indriyani. (2004) Validitas penelitian kualitatif. Retrieved from http://Indriyanimarifah.blogsspot.com/2014/04

Purwatiningsih. (2006). Metode Penelitian Kualitatif :Pendekatan Dalam Penelitian Pendidikan, Bahasa, Seni, dan Pembelajarannya. Makalah disampaikan pada pelatihan metodologi penelitian bagi guru FKIP Universitas Syiah Kuala Banda Aceh. .

Prastowo, Andi. (2012). Panduan kreatif membuat Bahan Ajar Inovatif. Jogjakarta : Diva Press.

Purwatiningsih. (2014). Buku Ajar, Pendekatan dan Dampaknya pada Proses Pembelajaran, Malang : Jurusan Seni dan desain

Purwatiningsih. (2012). Strategi Pembelajaran Seni Rupa SMA, Malang : CV Kurnia Samudra Ilmu.

Purwatiningsih. (2004). Aktivitas Seni dan Permainan Pasca Membaca Makalah Pelatihan Pengembangan Minat dan Kebiasaan Membaca, Dinas Pendidikan Kab. Jombang, Malang: YBS.

Soehardjo, A J. (2005). Pendidikan Seni, dari konsep sampai program, Buku Satu, Malang: Jurusan Seni dan Desain, FS UM, Malang.

Soehardjo, A J. (2011). Pendidikan Seni, Strategi penataan dan pelaksanaan pembelajaran seni, Buku 2, Malang: Bayumedia Publishing.

Soetopo, HB. (2002). Metodologi Penelitian Kualitatif : Dasar Teori dan Terapannya dalam Penelitian. Surakarta : UNS Press 